\title{
Red Sea MODIS Estimates of Chlorophyll a and Phytoplankton Biomass Risks to Saudi Arabian Coastal Desalination Plants
}

\author{
M. N. Gomaa ${ }^{1, *}$, D. J. Mulla ${ }^{2, * \mathbb{D}}$, J. C. Galzki ${ }^{2}$, K. M. Sheikho ${ }^{3}$, N. M. Alhazmi ${ }^{4}$ (D) H. E. Mohamed ${ }^{5}$ (D), \\ I. Hannachi ${ }^{5}$, A. M. Abouwarda ${ }^{5}$, E. A. Hassan ${ }^{5}$ (D) and W. W. Carmichael ${ }^{6}$
}

1 Department of Biochemistry, Deanship of Scientific Research, College of Science, University of Jeddah, Jeddah 21589, Saudi Arabia

2 Department Soil, Water \& Climate, University of Minnesota, St. Paul, MN 55108, USA; galzk001@umn.edu

3 King Abdulaziz City for Science and Technology (KACST), Riyadh 11442, Saudi Arabia; ksheukho1@gmail.com

4 Department of Biology, College of Science, University of Jeddah, Jeddah 21589, Saudi Arabia; nmalhazmi@uj.edu.sa

5 Department of Biology, College of Science and Arts, University of Jeddah, Jeddah 21589, Saudi Arabia; hatemelhady67@gmail.com (H.E.M.); imenhan@yahoo.fr (I.H.); ahmedabouwarda@gmail.com (A.M.A.); dressamahmad@gmail.com (E.A.H.)

6 Department Biological Sciences (Emeritus), Wright State University, Dayton, OH 45435, USA; wayne.carmichael@wright.edu

* Correspondence: mngomaa@gmail.com (M.N.G.); mulla003@umn.edu (D.J.M.)

\section{check for}

updates

Citation: Gomaa, M.N.; Mulla, D.J.; Galzki, J.C.; Sheikho, K.M.; Alhazmi, N.M.; Mohamed, H.E.; Hannachi, I.; Abouwarda, A.M.; Hassan, E.A.; Carmichael, W.W.et al. Red Sea MODIS Estimates of Chlorophyll a and Phytoplankton Biomass Risks to Saudi Arabian Coastal Desalination Plants. J. Mar. Sci. Eng. 2021, 9, 11. https://doi.org/10.3390/jmse9010011

Received: 29 November 2020 Accepted: 17 December 2020 Published: 23 December 2020

Publisher's Note: MDPI stays neutral with regard to jurisdictional clai$\mathrm{ms}$ in published maps and institutional affiliations.

Copyright: $@ 2020$ by the authors. Licensee MDPI, Basel, Switzerland. This article is an open access article distributed under the terms and conditions of the Creative Commons Attribution (CC BY) license (https:// creativecommons.org/licenses/by/ $4.0 /)$.
Abstract: Harmful algal blooms (HABs) and the high biomass associated with them have afflicted marine desalination plants along coastal regions around the world. Few studies of HABs have been conducted in the Red Sea, where desalination plants along the Saudi Arabian Red Sea coast provide drinking water for millions of people. This study was conducted along the Saudi Arabian Red Sea coast from 2014 to 2015 to assess the potential for using Moderate Resolution Imaging Spectroradiometer (MODIS) remote sensing of chlorophyll a ( $\mathrm{Chl} \mathrm{a)} \mathrm{or} \mathrm{fluorescence} \mathrm{line} \mathrm{height} \mathrm{(FLH)} \mathrm{to} \mathrm{identify} \mathrm{risks}$ for biofouling at these desalination plants. Ship-based surveys of phytoplankton were conducted along the Saudi Arabian coastline offshore of desalination plants at Jeddah, Al Shoaibah and Al Qunfudhuh to assess the density of phytoplankton populations and identify any potential HAB species. Ship-based surveys showed low to moderate concentrations of phytoplankton, averaging from 1800-10,000 cells $\mathrm{L}^{-1}$ at Jeddah, 2000-11,000 cells $\mathrm{L}^{-1}$ at Al Shoaibah and 1000-20,500 cells L $\mathrm{L}^{-1}$ at Al Qunfudhuh. Sixteen different species of potentially toxigenic HABs were identified through these surveys. There was a good relationship between ship-based total phytoplankton counts and monthly averaged coastal MODIS Chl a $\left(\mathrm{R}^{2}=0.49\right.$, root mean square error $\left.(\mathrm{RMSE})=0.27 \mathrm{mg} \mathrm{m}^{-3}\right)$ or FLH $\left(\mathrm{R}^{2}=0.47\right.$, RMSE $\left.=0.04 \mathrm{~mW} \mathrm{~m}^{-2} \mu \mathrm{m}^{-1} \mathrm{sr}^{-1}\right)$ values. Monthly average near shore Chl a concentrations obtained using MODIS satellite imagery were much higher in the Red Sea coastal areas at $\mathrm{Al}$ Qunfudhuh (maximum of about $1.3 \mathrm{mg} \mathrm{m}^{-3}$ ) than at Jeddah or Al Shoaibah (maximum of about 0.4 and $0.5 \mathrm{mg} \mathrm{m}^{-3}$, respectively). Chlorophyll a concentrations were generally highest from the months of December to March, producing higher risks of biofouling desalination plants than in other months. Concentrations decreased significantly, on average, from April to September. Long-term (2005-2016) monthly averaged MODIS Chl a values were used to delineate four statistically distinct zones of differing HAB biomass across the entire Red Sea. Sinusoidal functions representing monthly variability were fit to satellite Chl a values in each zone (RMSE values from 0.691 to $0.07 \mathrm{mg} \mathrm{m}^{-3}$, from Zone 1 to 4). December to January mean values and annual amplitudes for $\mathrm{Chl}$ a in these four sinusoidal functions decreased from Zones 1-4. In general, the greatest risk of HABs to desalination occurs during winter months in Zone 1 (Southern Red Sea), while HAB risks to desalination plants in winter months are low to moderate in Zone 2 (South Central Red Sea), and negligible in Zones 3 (North Central) and 4 (Northern).

Keywords: harmful algal blooms; Red Sea; remote sensing; desalination plant 


\section{Introduction}

Algal blooms frequently occur in coastal sea waters, examples include the Gulf of Mexico [1], south Florida coastlines [2], and Arabian Gulf [3]. These are primarily caused by nutrient enrichment, often associated with anthropogenic sources or natural upwelling. Algal blooms are also affected by temperature, wind, and salinity [4-9]. Sea color changes can be in response to chlorophyll a (Chl a) content associated with blooms. Harmful algal blooms (HABs) are characterized by high cell biomass that can cause biofouling of desalination plant filters that must be removed to protect the quality of drinking water. HABs are produced by several classes of microalgae, which are characterized by different colors ranging from blue-green to golden-brown to red. These classes may include diatoms, dinoflagellates, raphidophytes, cyanobacteria, prymnesiophytes, pelagophytes, and silicoflagellates [10].

Few studies have been conducted to measure the extent and severity of HABs in the Red Sea. An exception is the study of Genin et al. [11], which documented a serious incident involving algal and phytoplankton blooms in the Gulf of Aqaba as a result of the Mt. Pinatubo volcanic eruption. There is a serious need to better understand the potential frequency and severity of HABs in the Red Sea, especially along the eastern coast of the Red Sea bordering Saudi Arabia, which has three major desalination plants located at Jeddah, Al Shoaibah (100 km south of Jeddah), and Al Qunfudhuh (420 km south of Jeddah). These desalination plants provide drinking water for nearly 5 million residents. High biomass from coastal Red Sea HABs at these desalination plants could cause biofouling of the filters that protect drinking water supply [12]. Therefore, it is critically important to develop techniques to assess the frequency and severity of HABs in the eastern Red Sea along the Saudi Arabian coast.

Three contrasting methods have been developed to assess HABs in coastal regions of the world, including: (a) satellite optical remote sensing based on indirect measures of HAB biomass [2], (b) remote sensing of ecological characteristics such as sea surface temperature that affect HAB growth [13], or (c) association of HABs with other species, or with specific patterns in upwelling, wind, and ocean currents [14]. The focus of the present study is on optical remote sensing of Red Sea phytoplankton based on MODIS Aqua satellite imagery.

MODIS collects imagery at a revisit frequency of 16 days along the same ground track with a minimum pixel resolution of $250 \mathrm{~m}$. However, the level three MODIS product for chlorophyll a is provided by NASA at a pixel size of $4.6 \mathrm{~km}$. Since algal blooms vary significantly in density over distances on the order of $10 \mathrm{~m}$, MODIS estimates of $\mathrm{Chl}$ a are coarser in scale than that measured with ship-based sampling of marine phytoplankton. Satellite imagery averages variability across a pixel and offers data that are more representative of larger spatial areas than ship-based sampling. This can be beneficial for coarser scale analyses, to better portray spatial and temporal evolution of HAB blooms and potential risks to desalination plants along the coast.

MODIS collects remote sensing bands in the ultraviolet (UV), purple, blue, green, and red wavelengths. These wavelengths have proven to be useful for detection of algal blooms in marine environments [2,10]. Two major optical remote sensing techniques for detecting algal blooms have emerged using satellite-based MODIS Aqua imagery. These include measurements of either: (a) Chl a, or (b) Fluorescence line height (FLH). Satellite-based $\mathrm{Chl}$ a algorithms have been developed for the detection of blooms of the genus Karenia, Gymnodinium catenatum, Lingulodinium polyedra, Chattonella sp., and noxious diatoms [15,16]. More generally, satellite-based $\mathrm{Chl}$ a estimates have been used to map algal blooms in the East China or Yellow Seas [15], the Gulf of Arabia [17], and the Red Sea [18]. FLH has proven successful for mapping harmful algal blooms associated with high ship-based Chl a concentrations and a red tide in previous studies from the southwestern Florida coast [2]. The feasibility of using MODIS FLH to identify HABs in the Red Sea has not previously been assessed [19]. The objective of this study is to evaluate the feasibility of using MODIS $\mathrm{Chl}$ a and FLH remote sensing products to assess phytoplankton biomass densities, and 
identify the locations and seasonal timing of the risks they pose to desalination plants along eastern coastal regions in the Red Sea.

\section{Methods}

\subsection{Ship-Based Coastal Red Sea Surveys}

Ship-based surveys were conducted offshore of Jeddah, Al Shoaibah and Al Qunfudhuh, Saudi Arabia (Figure 1), where three major desalination plants are located. Ship surveys offshore of Jeddah were conducted on January 27, February 19, March 12, April 23, May 14, and June 10, 2015. Ship surveys were conducted offshore of Al Shoaibah on January 3, January 31, February 25, March 15, April 26, May 17, and June 9, 2015. Surveys offshore of Al Qunfudhuh were conducted on December 30, 2014, and on February 3, February 22, March 14, April 25, May 16, and June 11, 2015. A YSI EXO2 sonde was used to measure sea surface temperature, $\mathrm{Chl}$ a, nitrate- $\mathrm{N}$ and turbidity. Results from the shipbased Chl a measurements were, however, unreliable due to a malfunction of the probe. Three replicate samples were collected from the sea surface during ship-based surveys at each of three distances $(150,750$, and $1250 \mathrm{~m})$ offshore of the three desalination plant locations at Jeddah, Al Shoaibah and Al Qunfudhuh (Figure 1). Bathymetry of the Red Sea at these offshore distances ranged from $50 \mathrm{~m}$ to over $100 \mathrm{~m}$ depth. Results from these three offshore distances were averaged at each of the three locations for better comparison with $4.6 \mathrm{~km}$ scale MODIS Aqua satellite imagery pixels.

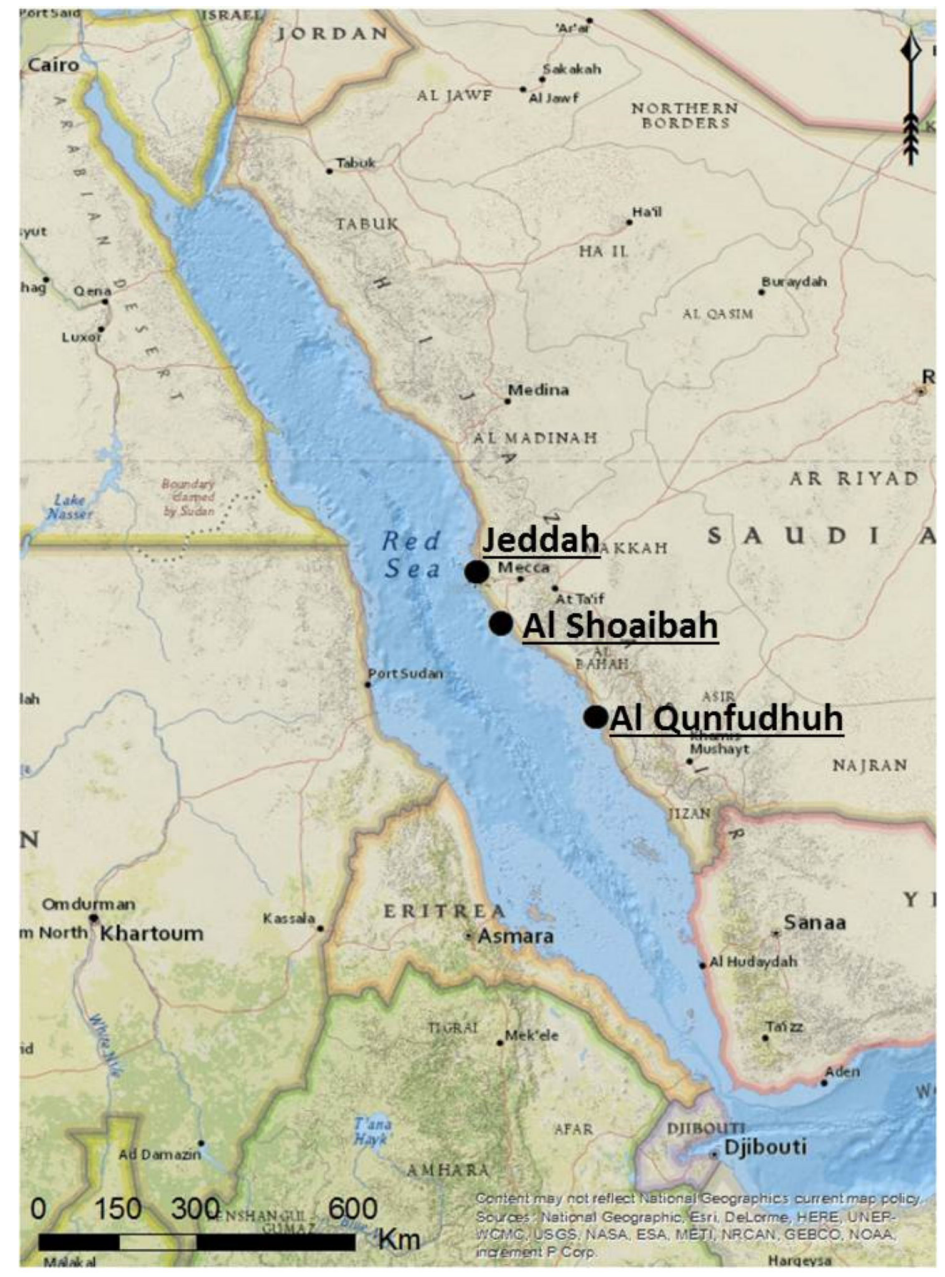

Figure 1. Location of ship-based Red Sea phytoplankton surveys near Jeddah, Al Shoaibah and Al Qunfudhuh, Saudi Arabia. 
A Niskin water sampler was used to collect three replicates of $1.7 \mathrm{~L}$ water samples at the surface from the three offshore distances at each coastal location [20]. Seven hundred $\mathrm{mL}$ was retained for chemical analysis of nitrogen (ammonium-, nitrite- and nitrate-N) in the lab. For determination of phytoplankton taxa [21] and quantitative determination of phytoplankton densities (counts), $1 \mathrm{~L}$ aliquots were preserved in amber-color bottles using a $4 \%$ iodine solution and stored in the dark at $4{ }^{\circ} \mathrm{C}$ pending analysis. The $1 \mathrm{~L}$ samples were concentrated via sedimentation in $1000 \mathrm{~mL}$ graduated cylinders according to the method detailed in Dolan and Marasse [22]. After settling for 4 to 8 days, the top $950 \mathrm{~mL}$ of the sample was slowly siphoned off with a small bore $(0.5 \mathrm{~cm}$ diameter $)$ tubing. The $50 \mathrm{~mL}$ remaining concentrate was used to count phytoplankton densities under an inverted microscope after settling for $24 \mathrm{~h}$ using Utermohl's method [23]. The entire surface of the settling chamber was examined at $400 \times$ magnification.

\subsection{Chlorophyll a}

The MODIS Aqua satellite platform operated by NASA [24] compiles and distributes monthly satellite composite images, which were acquired for the time period from December 2014 to June 2015 for comparison with ship-based measurements, and from Oct-May 2005-2016 for assessment of long-term patterns in Chl a. The MODIS monthly composites included 8 images in December, 2014, 8 images in January, 2015, 4 images in February, 2015, 6 images in 2015, 4 images in April 2015, 5 images in May, 2015, and 3 images in June of 2015. Chlorophyll a data were acquired at a $4.6 \mathrm{~km}$ resolution as standard mapped images from the MODIS Aqua platform's level 3 dataset. Near-surface concentrations of Chl a in the MODIS aqua algorithm are calculated by NASA using an empirical relationship derived from ratios of blue-to-green band reflectances. MODIS radiance values were corrected by NASA using a calibration process described by [25] that improves accuracy along scan edges. Satellite data were typically not available on the exact dates of ship-based sample collection. Monthly composite satellite data acquired from NASA were compared with ship-based phytoplankton counts using linear regression. Although monthly composite satellite data do not correspond to an exact date for ship-based sample collections, they nevertheless represent spatial and temporal differences that occur from month to month or across coastal locations (Jeddah, Al Shoaibah and Al Qunfudhuh) with Saudi Arabian desalination plants.

\subsection{Fluorescence Line Height}

Fluorescence, the main deactivation pathway for photosystem II, depends on chlorophyll concentration as well as quantum yield and water clarity and has been used as a proxy for phytoplankton concentration [2,13]. MODIS fluorescence bands focus on the red part of the spectrum where chlorophyll fluorescence dominates the total signal, and therefore suffers little from other interferences (CDOM, shallow bottom, and the atmosphere). Monthly composite images for FLH were collected from NASA's MODIS Aqua satellite platform as $4.6 \mathrm{~km}$ standard mapped images [26] for the time period from December 2014 to June 2015. MODIS bands 13,14, and 15 (centered at 667, 678, and $748 \mathrm{~nm}$, respectively, with $10 \mathrm{~nm}$ bandwidth) were used by NASA to estimate the FLH [27]. A baseline is first formed between radiances for bands 13 and 15, and this baseline is then subtracted from band 14 radiance to obtain the FLH $(\mathrm{FLH}=$ Band $14-(70 / 81) \times$ Band $13-(11 / 81) \times$ Band 15). FLH satellite data from these NASA composites were compared with ship-based phytoplankton counts using linear regression.

\subsection{Long-Term Red Sea Phytoplankton Biomass Mapping}

Red Sea Phytoplankton Biomass Provinces have been delineated along lines of equal latitude by Raitsos et al. [18] based on Chl a concentrations measured with MODIS satellite imagery. This study refines these Provinces for the entire Red Sea based on long-term (OctMay 2005-2016) spatial data trends in MODIS Chl a values. Data from June-September were not included, because phytoplankton densities are typically low during those months. 
Our goal in this refinement was to better reflect spatial and temporal patterns in phytoplankton densities that are not aligned with the generalized latitudinal boundaries proposed by Raitsos et al. [18]. In particular, this refinement is intended to better represent spatial and temporal patterns in phytoplankton biomass near Saudi Arabian coastal areas where major desalination plants are located. Monthly mean MODIS values of Chl a from 2005-2016 were calculated, and refined curvilinear boundaries based on these data were hand-digitized to delineate the four Red Sea Phytoplankton Biomass Zones. Chlorophyll a data within these boundaries were fit with a sinusoidal function [28] Asin $(\omega t+\varphi)+m$, where A is the fitted amplitude of Chl a $\left(\mathrm{mg} \mathrm{m}^{-3}\right), \omega$ is frequency $(2 \pi / 24), \mathrm{t}$ is month $(1=$ January $12=$ December), $\varphi$ is phase shift $(\pi)$ and $\mathrm{m}$ is the average fitted maximum value for $\mathrm{Chl}$ a $\left(\mathrm{mg} \mathrm{m}^{-3}\right)$. Accuracy of this model was determined by computing a root mean square error (RMSE). A one-way analysis of variance (ANOVA) test for mean differences was calculated on the data within each digitized boundary after checking the three assumptions for use of ANOVA.

\section{Results}

\subsection{Ship-Based Phytoplankton Densities}

Ship-based surveys generally showed low to moderate concentrations of phytoplankton, ranging from 1800-10,000 cells $\mathrm{L}^{-1}$ at Jeddah, 2000-11,000 cells $\mathrm{L}^{-1}$ at Al Shoaibah and 1000-20,500 cells $\mathrm{L}^{-1}$ at $\mathrm{Al}$ Qunfudhuh. Over 100 phytoplankton species were identified, belonging to the Cyanobacteria, Dictyocophyceae, Dinophyceae and Bacillariophyceae groups.

Potentially toxigenic HABs were identified at all three sampling site [21,29], the most common species included Prorocentrum lima, Ostreopsis ovata, Chattonella marina, Amphidinium sp., Alexandrium minitum, Dinophysis caudata, Dinophysis miles, Gymnodinium sp., Peridinium sp., Goniodoma sp., Protoperidinium depressum, Protoperidinium divergens, Protoperidinium curtipes, Protoperidinium bipes, Protoperidinium ovum, and Protoperidinium ovatum. On average cell densities of toxigenic HAB species were lowest at Jeddah $\left(1663\right.$ cells $\left.\mathrm{L}^{-1}\right)$ and Al Shoaibah (2997 cells L ${ }^{-1}$ ), and highest at Al Qunfudhuh (5834 cells $\mathrm{L}^{-1}$ ). Lowest concentrations of toxigenic $\mathrm{HAB}$ species $\left(<760\right.$ cells $\left.\mathrm{L}^{-1}\right)$ occurred during the months of April and May at all three locations. The average proportion of toxigenic HAB cell densities relative to total phytoplankton densities was $42 \%$ at Jeddah, $33 \%$ at Al Shoaibah and $47 \%$ at Al Qunfudhuh, with little seasonality at Jeddah and Al Shoaibah, and a tendency for elevated toxigenic HABs during the months of January, February, and March at Al Qunfudhuh.

\subsection{Accuracy of MODIS Chl $a$ and FLH Values for Estimating Total Phytoplankton}

Ship-based surveys of phytoplankton in the Red Sea in this study were compared with MODIS Aqua satellite-based estimates of Chl a and FLH for the Jeddah, Al Shoaibah and Al Qunfudhuh sites (Figure 2). A good relationship was observed between ship-based total phytoplankton counts and monthly averaged MODIS Chl a or FLH estimates (Figure 2a,b). Chlorophyll a values were an accurate predictor of total phytoplankton $\left(\mathrm{R}^{2}=0.49, \mathrm{RMSE}=0.27 \mathrm{mg} \mathrm{m}^{-3}\right)$, as were FLH values $\left(\mathrm{R}^{2}=0.47\right.$, RMSE $\left.=0.04 \mathrm{~mW} \mathrm{~m}^{-2} \mu \mathrm{m}^{-1} \mathrm{sr}^{-1}\right)$ ). Temporal trends in Chl a and FLH generally followed temporal trends in total phytoplankton, except in March at Jeddah $\left(10,467\right.$ cells $\left.\mathrm{L}^{-1}\right)$ and in June at Al Shoaibah $\left(11,300\right.$ cells $\left.\mathrm{L}^{-1}\right)$.

Total phytoplankton counts (Figure 3, blue bars) were highest at Al Qunfudhuh (average 10,502 cells $\mathrm{L}^{-1}$ ), the region closest to the Gulf of Aden. Densities at Al Shoaibah (6683 cells $\mathrm{L}^{-1}$ ) and Jeddah (4292 cells $\mathrm{L}^{-1}$ ) were much lower on average than at $\mathrm{Al}$ Qunfudhuh. Lowest concentrations occurred during the period from April to June, except for the June phytoplankton counts at Al Shoaibah and Al Qunfudhuh. Phytoplankton densities were highest in February or March at Jeddah and Al Shoaibah, and during the months of January, February, and March at Al Qunfudhuh. 

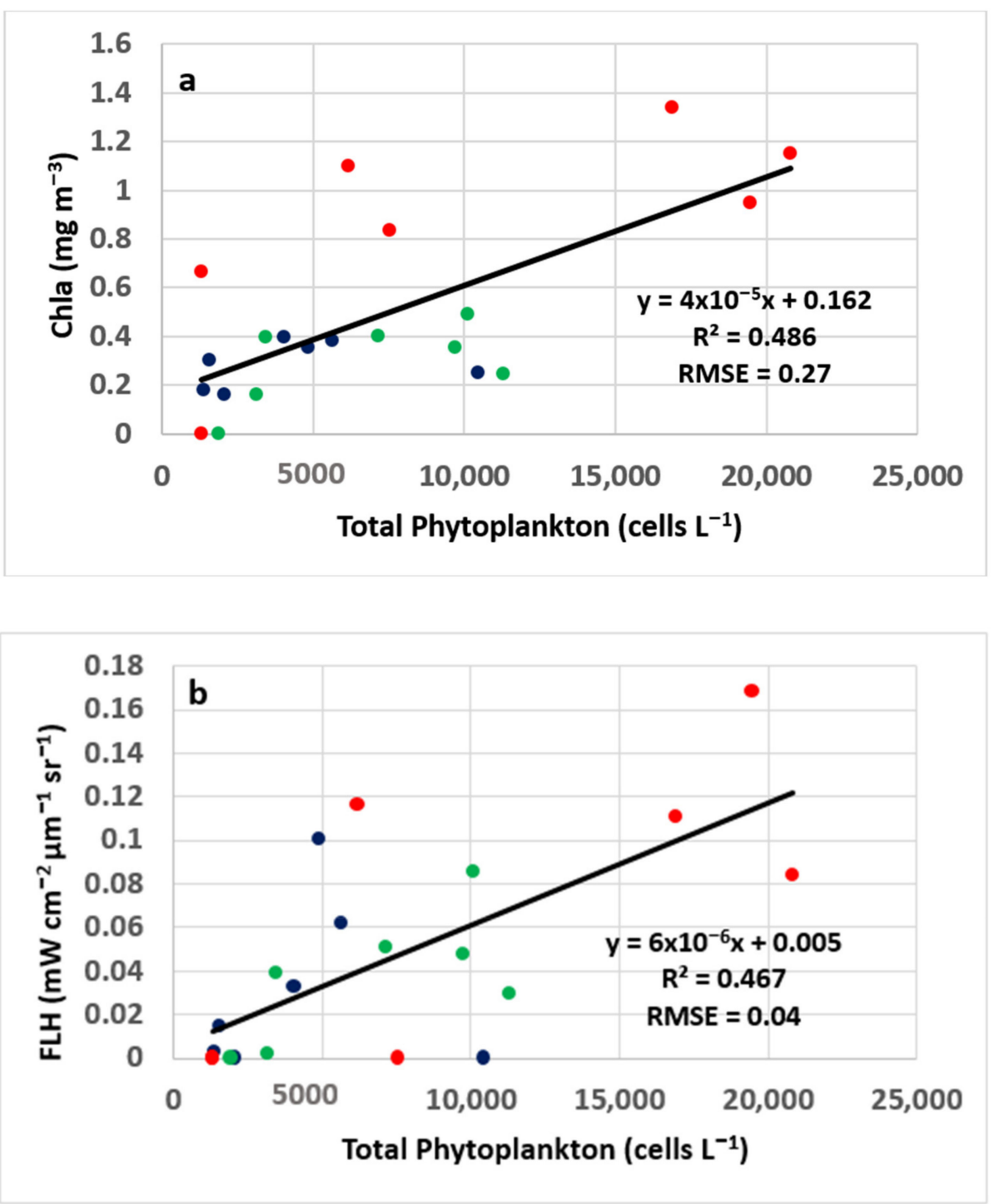

Figure 2. Linear regression modeling of (a) monthly averaged MODIS satellite estimates of chlorophyll a or (b) monthly averaged MODIS satellite estimates of FLH versus ship-based measurements of total phytoplankton counts at Jeddah (blue dots), Al Shoaibah (green dots) and Al Qunfudhuh (red dots).

Monthly average near shore $\mathrm{Chl}$ a concentrations obtained using MODIS satellite imagery (Figure 3, orange lines in left panels) were much higher in the Red Sea coastal areas at $\mathrm{Al}$ Qunfudhuh (maximum of $1.34 \mathrm{mg} \mathrm{m}^{-3}$ ) than at Jeddah or Al Shoaibah, which were generally $0.45 \mathrm{mg} \mathrm{m}^{-3}$ or lower (Figure 3). Concentrations at Jeddah and Al Shoaibah were comparable to each other during most months. Chlorophyll a concentrations were generally highest during the months of December, January, February and March. Concentrations decreased significantly, on average, during April, May, and June (Figure 3). Phytoplankton counts reached their maximum values at Al Qunfudhuh during January through March (Figure 3), corresponding to MODIS Chl a values that exceeded $1 \mathrm{mg} \mathrm{m}^{-3}$. To be conservative, we propose that HAB risks to desalination plants in the Red Sea should be carefully evaluated whenever MODIS Chl a values exceed $0.5 \mathrm{mg} \mathrm{m}^{-3}$.

Monthly average nearshore FLH measurements obtained using MODIS satellite imagery in the Red Sea for this study were generally higher at Al Qunfudhuh than at Jeddah or Al Shoaibah (Figure 3, orange lines in right panels). At Al Qunfudhuh, the highest FLH values $\left(0.17 \mathrm{~mW} \mathrm{~m}^{-2} \mu \mathrm{m}^{-1} \mathrm{sr}^{-1}\right)$ occurred during February, and were more than double FLH values at $\mathrm{Al}$ Shoaibah and Jeddah during the same month. FLH values were generally 
negligible or zero in the months of April and May at all locations (Figure 3), except for Al Qunfudhuh in May. During these months densities of phytoplankton were always less than 3156 cells $\mathrm{L}^{-1}$, and toxigenic HAB densities were always less than 756 cells $\mathrm{L}^{-1}$.
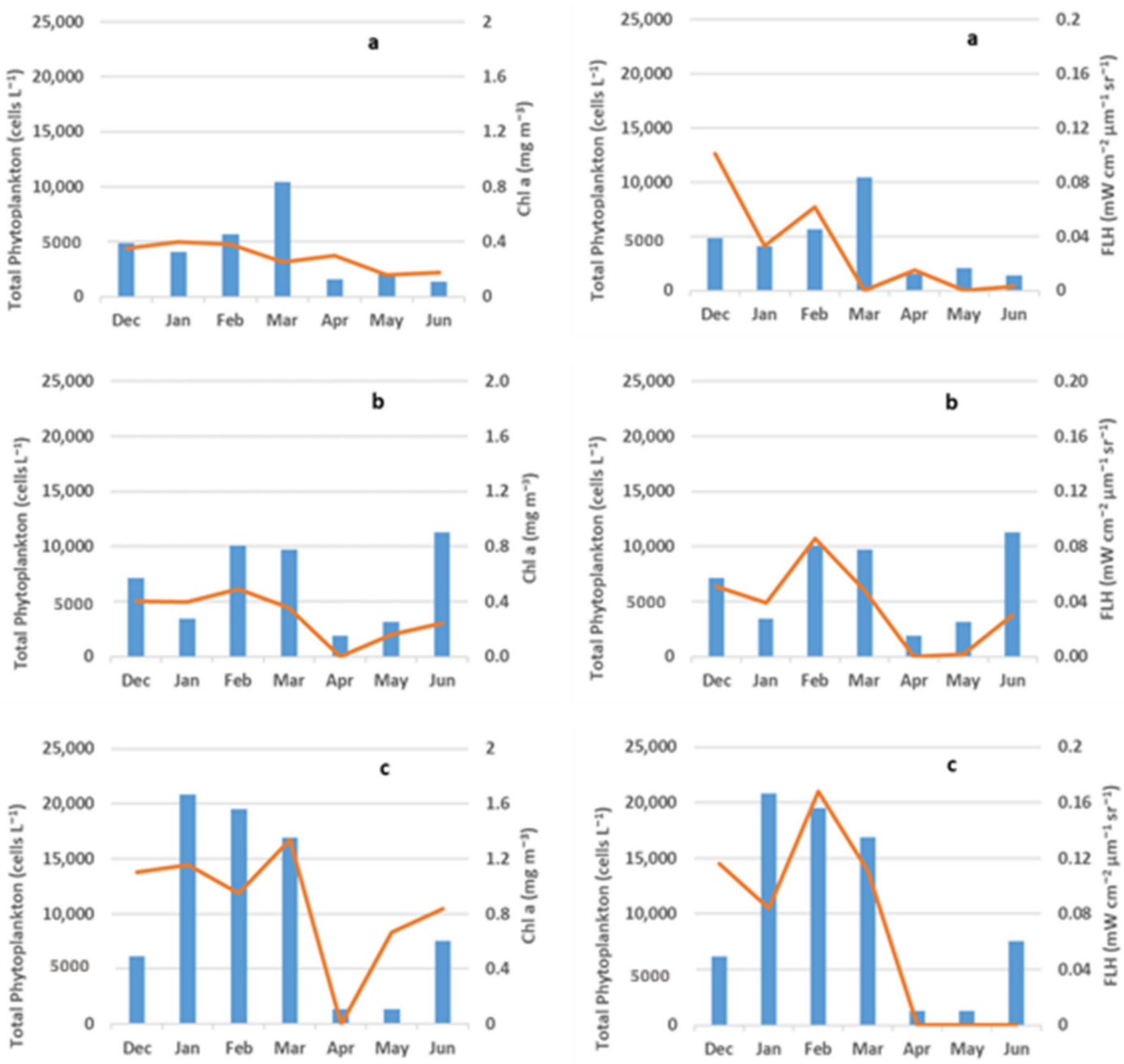

Figure 3. Comparison between ship-based total phytoplankton counts (blue bars) and monthly average MODIS satellite (orange lines) Chl a (left panels) or FLH (right panels) estimates for (a) Jeddah, (b) Al Shoaibah and (c) Al Qunfudhuh for the months of December, 2014 through June 2015.

\subsection{Phytoplankton Biomass Zone Delineation}

Phytoplankton biomass zone boundaries delineated by [18] were refined in the present study by incorporating information about spatial and temporal patterns in phytoplankton densities across the entire Red Sea based on long-term (Oct-May 2005-2016) trends in MODIS Chl a values (Figure 4). Temporal patterns in Chl a (Figure 4) were accurately represented with sinusoidal functions for each Zone (RMSE ranging from 0.691 to $0.07 \mathrm{mg} \mathrm{m}^{-3}$, in decreasing order from Zone 1 to 4 ) that peaked in the months of December to January and were lowest in the months of June to July. December to January mean values and annual amplitudes for $\mathrm{Chl}$ a in these four sinusoidal functions decreased from Zone 1 to 4. Phytoplankton Zone 1 represents the Southern Red Sea near the Gulf of Aden. This Zone has higher values of $\mathrm{Chl}$ a (December to January mean $2.6 \mathrm{mg} \mathrm{m}^{-3} \mathrm{Chl} \mathrm{a}$, amplitude $2.0 \mathrm{mg} \mathrm{m}^{-3}$ ) than any of the other three Zones. Chlorophyll a values are well above $0.5 \mathrm{mg} \mathrm{m}^{-3}$ in Zone 1 for all months between October and February. Phytoplankton Zone 2 was delineated in the South Central Red Sea, and has intermediate values of Chl a (December to January mean $0.50 \mathrm{mg} \mathrm{m}^{-3} \mathrm{Chl} \mathrm{a}$, amplitude $0.37 \mathrm{mg} \mathrm{m}^{-3}$ ). Chlorophyll a values are likely to exceed $0.5 \mathrm{mg} \mathrm{m}^{-3}$ in Zone 2 only during the months of December and January. 
Phytoplankton Zones 3 and 4 in the North Central and Northern Red Sea, respectively, exhibit very low Chl a values (December to January means of 0.25 and $0.22 \mathrm{mg} \mathrm{m}^{-3} \mathrm{Chl} \mathrm{a,}$ respectively, and amplitudes of $0.14 \mathrm{mg} \mathrm{m}^{-3}$ each). Chlorophyll a values in Zones 3 and 4 are unlikely to exceed $0.5 \mathrm{mg} \mathrm{m}^{-3}$ in any month. Phytoplankton Zones 3 and 4 represent portions of the Red Sea located far from shore, in areas which pose no direct risk to coastal desalination plants.

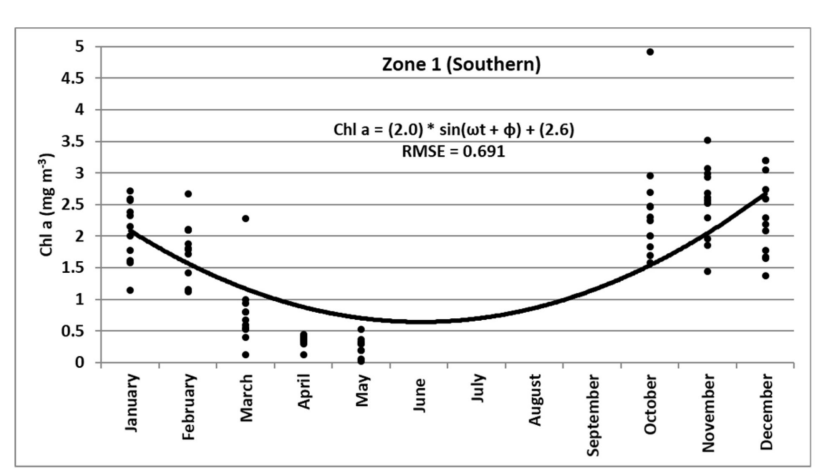

(a)

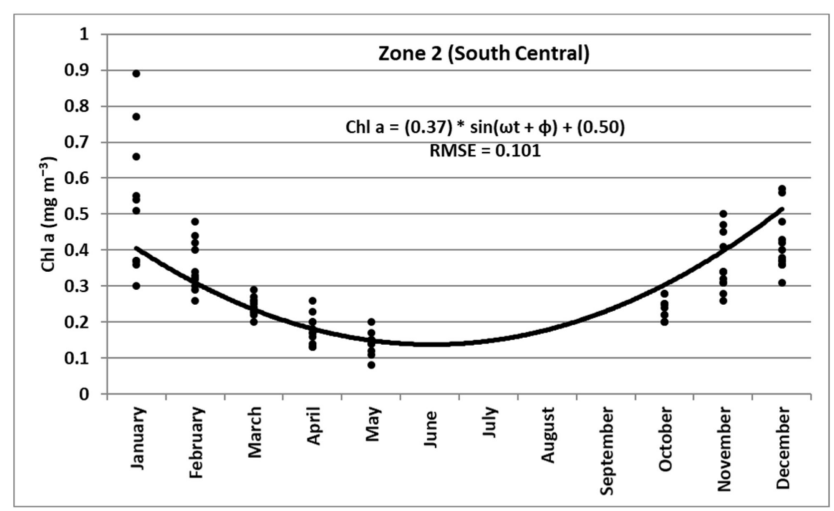

(b)

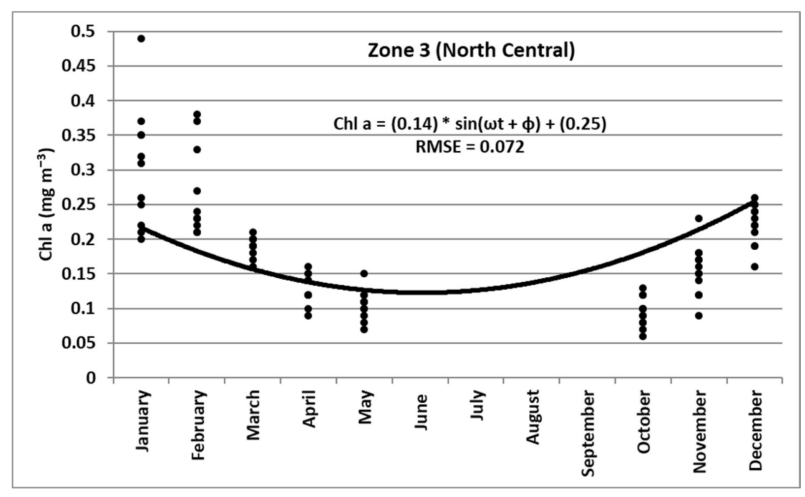

(c)

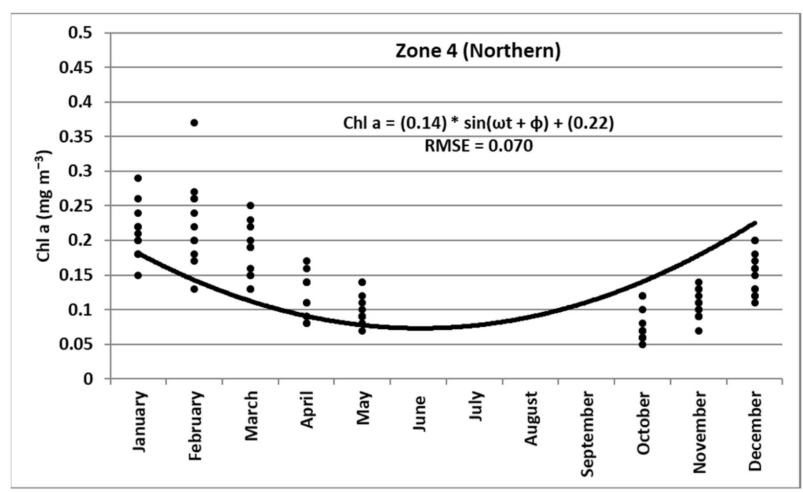

(d)

Figure 4. Monthly average MODIS Chl a values in four Red Sea Phytoplankton Biomass Zones from 2005-2016 with sinusoidal function $A \sin (\omega t+\varphi)+m$, where A is fitted amplitude, $\omega$ is frequency $(2 \pi / 24)$, $t$ is month (1= January $12=$ December), $\varphi$ is phase shift $(\pi)$ and $\mathrm{m}$ is average fitted maximum value for Chl a. (a) refers to Phytoplankton Biomass Zone 1 in the Southern Red Sea, (b) refers to Zone 2 in the South Central Red Sea and accompanying coastal areas, (c) refers to Zone 3 in the North Central Red Sea, and (d) refers to Zone 4 in the Northern Red Sea.

The spatial representation of Phytoplankton Biomass Zones (Figure 5) indicates that Zones 1, 3 and 4 cover a majority of the Red Sea, while Zone 2 is essentially a transitional area between Zones 1 and 3. In contrast with a previous study on phytoplankton zone delineation [18], the refined zones in the present study show a marked northern extension of zone boundaries along coastal regions along both the eastern and western coastlines of the Red Sea. This northward extension has important implications for protection of coastal desalination plants, as these coastal areas have higher phytoplankton biomass than would be inferred using previously defined zones [18] that are delineated using horizontal latitude-based boundaries. 


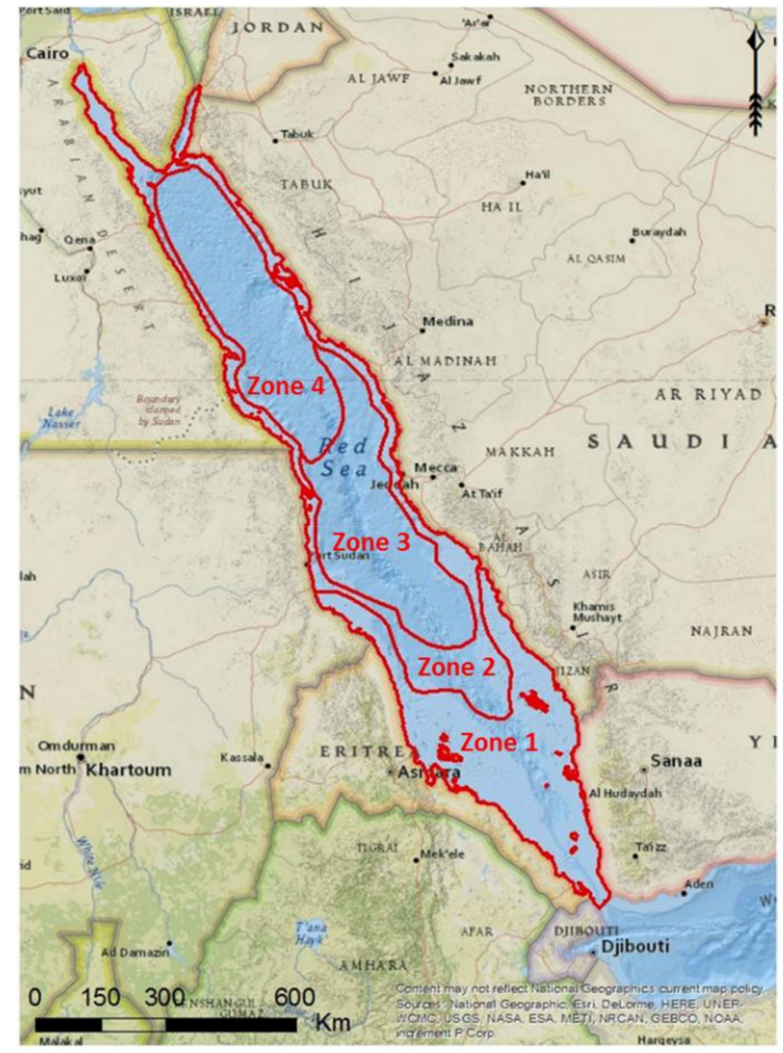

Figure 5. Red Sea Phytoplankton Biomass Zones delineated based on Chl a data collected using MODIS imagery from 2005-2016.

Phytoplankton Biomass Zone 1 includes the Al Qunfudhuh desalination plant. Zone 1 exhibits MODIS Chl a values that frequently exceed $1 \mathrm{mg} \mathrm{m}^{-3}$ during the months of October through February. Phytoplankton Zone 2 includes the Jeddah and Al Shoaibah desalination plants, as well as all Saudi Arabian desalination plants in the Northern Red Sea. It also includes much of the populated western Saudi Arabian coastline. MODIS $\mathrm{Chl}$ a values in Zone 2 frequently vary between 0.5 and $1.0 \mathrm{mg} \mathrm{m}^{-3}$ during the month of January. Phytoplankton Zone 3 occurs in offshore regions of the North Central Red Sea and does not include any desalination plants. MODIS Chl a values in Zone 3 are highest during the month of January, when values may occasionally approach $0.5 \mathrm{mg} \mathrm{m}^{-3}$. Phytoplankton Zone 4 occurs in offshore regions of the Northern Red Sea and does not include any desalination plants. MODIS Chl a values in Zone 4 are highest during the month of February, but never exceed $0.4 \mathrm{mg} \mathrm{m}^{-3}$.

MODIS satellite imagery in the Red Sea (exemplified by trends during 2015 as shown in Figure 6) shows a pattern for high HAB biomass that develops offshore of Yemen in Phytoplankton Zone 1 near the Gulf of Aden during October. This high phytoplankton biomass subsequently migrates in the northeasterly direction towards Al Qunfudhuh during November, December, and January before decreasing in March. Based on data collected during our ship excursions near the western Saudi Arabian coastline (Section 3.1), nearly half the phytoplankton biomass in Zone 1 during the months of January, February and March may be comprised of toxigenic species. Phytoplankton Zone 2, which includes much of the Red Sea shoreline, reaches a peak HAB biomass in December and January. Phytoplankton Zone 3 reaches a maximum in January (Figure 4), while Zone 4 peaks in February (Figure 4). However, HAB biomass is minimal in Zones 3 and 4. 


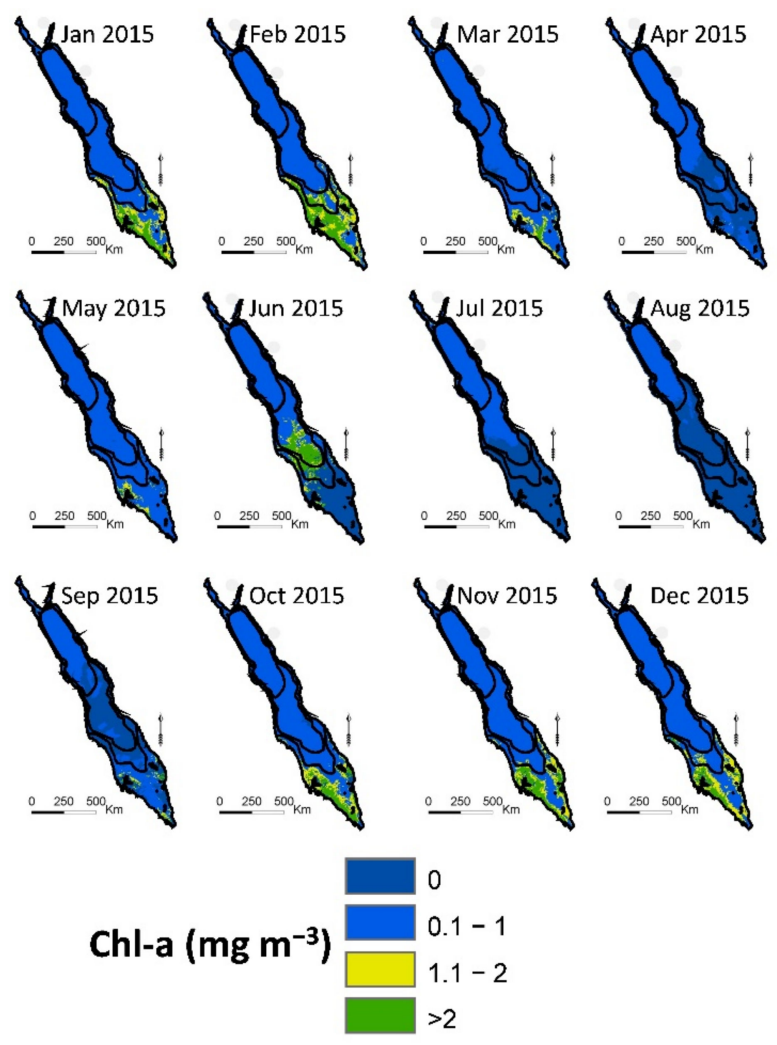

Figure 6. MODIS-based monthly average Red Sea chlorophyll a levels (see color scale in legend) during 2015 with Phytoplankton Biomass Zone boundaries (black lines) originally shown in Figure 5.

\section{Discussion}

In comparison with results from this study, ship-based surveys conducted along the southwestern Florida coastline during an HAB event [2] showed moderate $\left(10^{4}\right.$ to $10^{5}$ cells L $\left.{ }^{-1}\right)$ to high $\left(>10^{5}\right.$ cells $\left.\mathrm{L}^{-1}\right)$ concentrations of Karenia brevis. The highest concentrations of phytoplankton in the present Red Sea study were in the low part of the high range in the Florida study [2]. During a severe 2008 HAB event in the Arabian Gulf [3,30-32], very high $\left(>10^{7}\right.$ cells $\left.\mathrm{L}^{-1}\right)$ concentrations of Cochlodinium polykrikoides caused the closure of five desalination plants and resulted in severe fish mortality, similar to effects of severe HAB events in other parts of the world [33-41]. Concentrations of HABs in the 2008 Arabian Gulf event [3] were much higher than any phytoplankton concentrations measured in the Red Sea during the present study. Thus, the risk from HABs to coastal desalination plants is smaller along the Red Sea Saudi Arabian coastline than along the Arabian Gulf coastline.

Based on results presented in Figure 2 above, MODIS satellite $\mathrm{Chl}$ a values are a good predictor of total phytoplankton in the eastern coastal region of the Red Sea. Accuracy of the Chl a model presented in Figure $2 \mathrm{a}\left(\mathrm{R}^{2}=0.49\right.$, $\left.\mathrm{RMSE}=0.27 \mathrm{mg} \mathrm{m}^{-3}\right)$ was much better than the $\mathrm{Chl}$ a model $\left(\mathrm{R}^{2}=0.27\right)$ developed for coastal Florida in a $30 \mathrm{~km}$ study area during December of 2004 [2]. Accuracy of the FLH model presented in Figure $2 b\left(R^{2}=0.47\right.$, RMSE $\left.=0.04 \mathrm{~mW} \mathrm{~m}^{-2} \mu \mathrm{m}^{-1} \mathrm{sr}^{-1}\right)$ was somewhat weaker than the FLH model $\left(\mathrm{R}^{2}=0.58\right)$ developed in the Arabian Gulf and Gulf of Oman from 2006 to 2011 [19]. These comparisons provide confidence that the $\mathrm{Chl}$ a and FLH models in the present study are an accurate measure of phytoplankton abundance in the Red Sea. However, monthly composite images from MODIS were not always temporally well aligned with ship-based measurements of phytoplankton (e.g., during May and June of 2015, when the ship excursions were a week later or a week earlier, respectively, than the MODIS imagery used to construct monthly composites). This mismatch in temporal alignment could have contributed to a slight weakening of the $\mathrm{Chl}$ a and FLH models developed in this study. During severe algal blooms observed in the Arabian Gulf starting in August 2008 [30-32], Chl a concentrations 
often exceeded $2 \mathrm{mg} \mathrm{m}^{-3}$, much higher than the values observed in the present study. During the severe algal blooms that were observed in a previous study located along the southwestern Florida coastal region starting in October 2004 [2], FLH values often exceeded $0.2 \mathrm{~mW} \mathrm{~m}^{-2} \mu \mathrm{m}^{-1} \mathrm{sr}^{-1}$. FLH values at Jeddah or Al Shoaibah were generally lower than these levels, and rarely exceeded $0.1 \mathrm{~mW} \mathrm{~m}^{-2} \mu \mathrm{m}^{-1} \mathrm{sr}^{-1}$.

In cases where a single toxigenic $\mathrm{HAB}$ species was responsible for red tides (e.g., in Florida [2] and Arabian Gulf [19]), satellite estimates of FLH were superior to Chl a at detecting toxigenic HAB species. The relationship between FLH and total phytoplankton (or indirectly the relatively constant proportion of toxigenic HABs) was very good in our study, but not as strong as the relationship between $\mathrm{Chl}$ a and total phytoplankton (Figure 2a vs. Figure 2b). However, there were more than 15 toxigenic HAB species in our study, and this may be why FLH did not perform as well as in the Florida or Arabian Gulf studies at identifying toxigenic HAB species.

Ship-based surveys of phytoplankton in the offshore areas of Jeddah, Al Shoaibah and Al Qunfudhuh were limited in spatial extent and were time consuming to conduct. Satellite remote sensing, in contrast, covers the entire Red Sea at a pixel resolution of $4.6 \mathrm{~km}$ on a side (area of $21.16 \mathrm{~km}^{2}$ ), and images are collected at regular time intervals using a consistent methodology. This suggests the possibility of monitoring phytoplankton biomass in the Red Sea using satellite remote sensing, in order to have early warning of phytoplankton densities that could pose risks to Saudi Arabian coastal desalination plants.

High levels of turbidity can interfere with MODIS Chl a estimates [42]. However, measured turbidities in the coastal Red Sea areas from the present study were relatively low. This observation is consistent with previous findings showing that the entire Red Sea basin (excepting the Farasan Islands in the Southern Red Sea) is classified as optically clear Case-I waters [43]. There are no major rivers discharging sediment or colored dissolved organic matter into the eastern side of the Red Sea. Average annual ship-based turbidity levels in the present study at Jeddah and Al Shoaibah were 0.64 and 0.61 Formazin Nephelometric Units (FNU), respectively, with values that increased to only $1.0 \mathrm{FNU}$ during the months of January through March. These highest FNU values are at the low end of FNU values measured in the Gulf of Finland during August of 1997 [44], which ranged from 1 to 8 FNU. FNU values at Jeddah and Al Shoaibah are low, implying that turbidity is unlikely to interfere with MODIS Chl a estimates in most months. Average annual ship-based turbidity at Al Qunfudhuh was 1.1 FNU, and highest turbidity readings ( $>2 \mathrm{FNU}$ ) at this location occurred during April to August, when ship-based total phytoplankton densities were generally lowest. Turbidity at Al Qunfudhuh is likely to interfere only slightly with MODIS estimates of $\mathrm{Chl}$ a during the months from April to August, when lowest total phytoplankton densities were observed. In future studies, it is recommended to use a MODIS two-band (red and near infrared) model [45] for Chl a estimates in the Southern Red Sea, to further reduce concerns over potentially small interferences from turbidity [42], particularly at Al Qunfudhuh.

The Red Sea is recognized as an oligotrophic marine water body [18], with nutrient limitations from nitrate- $\mathrm{N}$ becoming less severe from the northern regions to the southern regions. Seasonal trends in total phytoplankton counts from this study are consistent with strong winds from the southeast in October, bringing an influx of cold, low salinity, nutrient rich water to the southern Red Sea from the Gulf of Aden [18,46] In the present study, ship-based nitrate-N concentrations at $\mathrm{Al}$ Qunfudhuh increased from $0.15 \mathrm{mg} \mathrm{L}^{-1}$ in August to $1.3 \mathrm{mg} \mathrm{L}^{-1}$ in November [21]. This influx of nutrients initiates a marked increase in phytoplankton populations from summer to late fall in the portion of the southern Red Sea that includes Al Qunfudhuh. Seasonal trends in phytoplankton offshore of Jeddah and Al Shoaibah generally occur for the same reasons as trends at Al Qunfudhuh, but the influx of south easterly winds and cold, nutrient rich water from the Gulf of Aden are greatly diminished at Jeddah and Al Shoaibah. This trend, combined with lower sea surface temperatures [46] at Jeddah and Al Shoaibah than Al Qunfudhuh (ship-based SST values were about $2{ }^{\circ} \mathrm{C}$ smaller at Jeddah and Al Shoaibah than at Al Qunfudhuh $\left(29.7^{\circ} \mathrm{C}\right)$ 
during November), causes productivity at Jeddah and Al Shoaibah to be smaller than at $\mathrm{Al}$ Qunfudhuh. Wind reverses direction in summer, causing nutrient deficiencies that limit phytoplankton growth in the southern Red Sea. SST increases on average by $6{ }^{\circ} \mathrm{C}$ from winter to summer in any given portion of the Red Sea [18,46], but more importantly, there is a marked increase in SST from southeast to northwest during any given season, driving increased phytoplankton biomass from southeast to northwest.

The lowest phytoplankton biomass at Al Qunfudhuh (as well as Jeddah and Al Shoaibah) typically occurs during the late summer months. An exception to this pattern of phytoplankton biomass in relation to seasonal patterns in wind and SST, were the uncharacteristically high phytoplankton counts during June. This pattern is explained by Raitsos et al. [18] as being caused by anti-cyclonic eddies that temporarily bring colder, nutrient rich waters [46] or nutrient-rich wind-blown dust to the Al Shoaibah and $\mathrm{Al}$ Qunfudhuh regions. Remote sensing offers the potential for early detection of these upwelling anomalies in order to better protect Saudi Arabian coastal desalination plants.

Sea water desalination provides the ultimate source for fresh water in Arabian region [47], which has domestic, industrial and agricultural uses. However, HABs impose great challenges for production of desalinized water [47-49]. Monitoring and early warning of HAB events is key to managing desalination processes and water production [50]. Remote sensing analysis has been extensively explored to establish reliable early warning tools to predict HAB events in this study and other parts of the world [30-32,51-53]. In future, it would be useful to combine remote sensing with more general models for risk of HAB biomass to coastal desalination plants in the Red Sea that simultaneously account for spatial and temporal patterns in satellite-based SST and Chl a concentrations, along with measurements of wind speed and direction.

\section{Conclusions}

Satellite-based phytoplankton risk zones for the onset of HAB biomass risks in marine coastal regions are greatly needed to enhance the protection of desalination plants, as well as for the protection of marine habitats, fisheries, and recreation areas. HAB presence and severity has been rarely studied in the Red Sea, and has never been studied using satellite based FLH products. MODIS satellite imagery for $\mathrm{Chl}$ a values were used to assess HAB risks and delineate four Phytoplankton Biomass Zones with distinctly different spatial and temporal patterns of $\mathrm{Chl}$ a values along Saudi Arabian coastal regions in the Red Sea for the first time. These coastal regions include Jeddah, Al Shoaibah and Al Qunfudhuh, which each rely heavily on drinking water supplies produced from desalination plants. HAB risks were significant offshore of Al Qunfudhuh and in the Red Sea south of Al Qunfudhuh (Phytoplankton Biomass Zone 1) during fall and winter months. Therefore, this region exhibits serious $\mathrm{HAB}$ risks in winter months that could produce biofouling threats to nearby coastal desalination plants. In contrast, Phytoplankton Biomass Zone 2, which is near the populated coastal Saudi Arabian areas north of Al Qunfudhuh (e.g., Jeddah and $\mathrm{Al}$ Shoaibah), showed low to moderate levels of HAB biomass during fall and winter months. Remote sensing of $\mathrm{Chl}$ a values shows promise for use in estimating the timing and magnitude serious HAB onset in the Red Sea, just as it has shown promise for the same purpose in the Arabian Gulf, southwestern coastal Florida region, and East China and Yellow Seas.

Author Contributions: M.N.G. managed and supervised all aspects of the project and developed the concept for the research; D.J.M. conducted statistical analysis of data, wrote the manuscript, and developed the concept for the research; J.C.G. conducted the remote sensing analysis; K.M.S. shared in project preparation and consultation; N.M.A. helped with logistics and chemical analysis; I.H. conducted laboratory analyses of phytoplankton densities, summarized, and interpreted phytoplankton results; H.E.M. collected marine phytoplankton and chemical data, and assisted with writing the manuscript; A.M.A. collected marine phytoplankton and chemical data; E.A.H. helped in data statistical analysis and chemical analysis; W.W.C. collected and interpreted marine phytoplankton data. All authors have read and agreed to the published version of the manuscript. 
Funding: This research was funded by King Abdulaziz City for Science and Technology, grant number 12-ENV3086-03 from the Strategic Technologies program.

Data Availability Statement: The data presented in this study are available on request from the corresponding authors. The data are not publicly available due to privacy concerns.

Acknowledgments: The research team expresses their gratitude and appreciation to King Abdulaziz City for Science and Technology for providing research grant No. 12-ENV3086-03 from the Strategic Technologies program of the Saudi Arabian KACST-CNPSTI. We appreciate the scientific research deanship from the science and technology unit at King Abdulaziz University for their highly skilled guidance during the course of research.

Conflicts of Interest: The authors declare no conflict of interest.

\section{References}

1. Stumpf, R.P.; Culver, M.; Tester, P.; Tomlinson, M.; Kirkpatrick, G.; Pederson, B.; Truby, E.; Ransibrahmanakul, V.; Soracco, M. Monitoring Karenia brevis blooms in the Gulf of Mexico using satellite ocean color imagery and other data. Harmful Algae 2003, 2, 147-160. [CrossRef]

2. Hu, C.; Muller-Karger, F.E.; Taylor, C.J.; Carder, K.L.; Kelble, C.; Johns, E.; Heil, C.A. Red tide detection and tracing using MODIS fluorescence data: A regional example in SW Florida coastal waters. Remote Sens. Environ. 2005, 97, 311-321. [CrossRef]

3. Richlen, M.L.; Morton, S.L.; Jamali, E.A.; Rajan, A.; Anderson, D.M. The catastrophic 2008-2009 red tide in the Arabian gulf region, with observations on the identification and phylogeny of the fish-killing dinoflagellate Cochlodinium polykrikoides. Harmful Algae 2010, 9, 163-172. [CrossRef]

4. Brandenburg, K.M.; Domis, L.N.D.S.; Wohlrab, S.; Krock, B.; John, U.; Van Scheppingen, Y.; Van Donk, E.; Van De Waal, D.B. Combined physical, chemical and biological factors shape Alexandrium ostenfeldii blooms in The Netherlands. Harmful Algae 2017, 63, 146-153. [CrossRef] [PubMed]

5. Zhou, Z.-X.; Yu, R.-C.; Zhou, M.-J. Resolving the complex relationship between harmful algal blooms and environmental factors in the coastal waters adjacent to the Changjiang River estuary. Harmful Algae 2017, 62, 60-72. [CrossRef] [PubMed]

6. Tian, D.; Xie, G.; Tian, J.; Tseng, K.-H.; Shum, C.K.; Lee, J.; Liang, S. Spatiotemporal variability and environmental factors of harmful algal blooms (HABs) over western Lake Erie. PLoS ONE 2017, 12, e0179622. [CrossRef]

7. Larsson, M.E.; Ajani, P.A.; Rubio, A.M.; Guise, K.; McPherson, R.G.; Brett, S.J.; Davies, K.P.; Doblin, M.A. Long-term perspective on the relationship between phytoplankton and nutrient concentrations in a southeastern Australian estuary. Mar. Pollut. Bull. 2017, 114, 227-238. [CrossRef] [PubMed]

8. Cui, L.; Lu, X.; Dong, Y.; Cen, J.; Cao, R.; Pan, L.; Lü, S.; Ou, L.-J. Relationship between phytoplankton community succession and environmental parameters in Qinhuangdao coastal areas, China: A region with recurrent brown tide outbreaks. Ecotoxicol. Environ. Saf. 2018, 159, 85-93. [CrossRef] [PubMed]

9. Watson, S.B.; Miller, C.; Arhonditsis, G.; Boyer, G.L.; Carmichael, W.; Charlton, M.N.; Confesor, R.; DePew, D.C.; Höök, T.O.; Ludsin, S.A.; et al. The re-eutrophication of Lake Erie: Harmful algal blooms and hypoxia. Harmful Algae 2016, 56, 44-66. [CrossRef]

10. Stumpf, R.P.; Tomlinson, M.C. Remote sensing of harmful algal blooms. In Remote Sensing of Coastal Aquatic Environments; Miller, R.L., Del Castillo, C.E., McKee, B.E., Eds.; Springer: Dordrecht, The Netherlands, 2005; pp. 277-296.

11. Genin, A.; Lazar, B.; Brenner, S. Vertical mixing and coral death in the Red Sea following the eruption of Mount Pinatubo. Nat. Cell Biol. 1995, 377, 507-510. [CrossRef]

12. Laycock, M.V.; Anderson, N.M.; Naar, J.; Goodman, A.; Easy, D.J.; Donovan, M.A.; Li, A.; Quilliam, M.A.; Al Jamali, E.; Alshihi, R. Laboratory desalination experiments with some algal toxins. Desalination 2012, 293, 1-6. [CrossRef]

13. Eppley, R. Temperature and phytoplankton growth in the sea. Fish. Bull. 1972, 70, 1063-1085.

14. Banse, K. Seasonality of phytoplankton chlorophyll in the central and northern Arabian sea. Deep Sea Res. Part A Oceanogr. Res. Pap. 1987, 34, 713-723. [CrossRef]

15. Ahn, Y.-H.; Shanmugam, P. Detecting the red tide algal blooms from satellite ocean color observations in optically complex Northeast-Asia Coastal waters. Remote Sens. Environ. 2006, 103, 419-437. [CrossRef]

16. Wang, C. Automatic Red Tide Detection Using MODIS Satellite Images. Master's Thesis, University of South Florida, Tampa, FL, USA, 2009.

17. Zhao, J.; Ghedira, H. Monitoring red tide with satellite imagery and numerical models: A case study in the Arabian Gulf. Mar. Pollut. Bull. 2014, 79, 305-313. [CrossRef] [PubMed]

18. Raitsos, D.E.; Pradhan, Y.; Brewin, R.J.W.; Stenchikov, G.; Hoteit, I. Remote Sensing the Phytoplankton Seasonal Succession of the Red Sea. PLoS ONE 2013, 8, e64909. [CrossRef] [PubMed]

19. Al Shehhi, M.R.; Gherboudj, I.; Zhao, J.; Mezhoud, N.; Ghedira, H. Evaluating the performance of MODIS FLH ocean color algorithm in detecting the Harmful Algae Blooms in the Arabian Gulf and the Gulf of Oman. In Proceedings of the Oceans 2013 MTS/IEEE Conference, San Diego, CA, USA, 23-27 September 2013. 
20. Reguera, B.; Alonso, R.; Moreira, A.; Méndez, S.; Dechraoui-Bottein, M.-Y. Guide for Designing and Implementing a Plan to Monitor Toxin-Producing Microalgae, 2nd ed.; United Nations Educational, Scientific and Cultural Organization (UNESCO): Paris, France, 2016; pp. 1-66.

21. Gomaa, M.N.; Hannachi, I.; Carmichael, W.W.; Al-Hazmi, M.A.; Abouwarda, A.M.; Mostafa, E.A.; Mohamed, H.E.; Sheikho, K.M.; Mulla, D.J. Low diversity triggers harmful algae bloom (HAB) occurrence adjacent to desalination plants along the Red Sea. Desalin. Water Treat. 2018, 114, 1-12. [CrossRef]

22. Dolan, J.R.; Marasse, C. Planktonic ciliate distribution relative to a deep chlorophyll maximum: Catalan Sea, NW Mediterranean, June 1993. Deep Sea Res. 1995, 42, 1965-1987. [CrossRef]

23. Utermöhl, H. Zurvervolkommungder quantitativen phytoplankton Methodik. Mitt. Int. Ver. Theor. Angew. Limnol. 1958, 9, 1-38.

24. NASA Goddard Space Flight Center; Ocean Ecology Laboratory; Ocean Biology Processing Group. Coastal Zone Color Scanner Experiment (CZCS) Chlorophyll Data; 2014 Reprocessing; NASA OB.DAAC: Greenbelt, MD, USA, 2014. [CrossRef]

25. Meister, G.; Franz, B.A. Corrections to the MODIS Aqua Calibration Derived from Modis Aqua Ocean Color Products. IEEE Trans. Geosci. Remote. Sens. 2014, 52, 6534-6541. [CrossRef]

26. Tomlinson, M.C.; Wynne, T.; Stumpf, R. An evaluation of remote sensing techniques for enhanced detection of the toxic dinoflagellate, Karenia brevis. Remote Sens. Environ. 2009, 113, 598-609. [CrossRef]

27. NASA Goddard Space Flight Center; Ocean Ecology Laboratory; Ocean Biology Processing Group. Moderate-Resolution Imaging Spectroradiometer (MODIS) Aqua Fluorescence Line Height Data; 2014 Reprocessing; NASA OB.DAAC: Greenbelt, MD, USA, 2014.

28. Mao, Z.; Mao, Z.; Jamet, C.; Linderman, M.A.; Wang, Y.; Chen, X. Seasonal Cycles of Phytoplankton Expressed by Sine Equations Using the Daily Climatology from Satellite-Retrieved Chlorophyll-a Concentration (1997-2019) Over Global Ocean. Remote Sens. 2020, 12, 2662. [CrossRef]

29. Gomaaa, M.N.; Al-Hazmic, M.A.; Mohamed, H.E.; Mullae, D.J.; Hannachid, I.; Sheikhof, K.M.; Abouwardad, A.M.; Mostafad, E.A.H.; Carmichaelg, W.W. A model to predict HAB occurrence near desalination plants in the Red Sea. Desalin. Water Treatment 2018, 129, 1-13. [CrossRef]

30. Al Shehhi, M.R.; Gherboudj, I.; Ghedira, H. An overview of historical harmful algae blooms outbreaks in the Arabian Seas. Mar. Pollut. Bull. 2014, 86, 314-324. [CrossRef] [PubMed]

31. Zhao, J.; Temimi, M.; Ghedira, H. Characterization of harmful algal blooms (HABs) in the Arabian Gulf and the Sea of Oman using MERIS fluorescence data. ISPRS J. Photogramm. Remote. Sens. 2015, 101, 125-136. [CrossRef]

32. Zhao, J.; Temimi, M.; Al Kitbi, S.; Mezhoud, N. Monitoring HABs in the shallow Arabian Gulf using a qualitative satellite-based index. Int. J. Remote Sens. 2016, 37, 1937-1954. [CrossRef]

33. Kim, Y.; Yoo, S.; Son, Y.B. Optical discrimination of harmful Cochlodinium polykrikoides blooms in Korean coastal waters. Opt. Express 2016, 24, A1471-A1488. [CrossRef] [PubMed]

34. Gárate-Lizárraga, I. Bloom of Cochlodinium polykrikoides (Dinophyceae: Gymnodiniales) in Bahía de La Paz, Gulf of California. Mar. Pollut. Bull. 2013, 67, 217-222. [CrossRef] [PubMed]

35. Dorantes-Aranda, J.J.; La Parra, L.M.G.-D.; Alonso-Rodríguez, R.; Morquecho, L.; Voltolina, D. Toxic effect of the harmful dinoflagellate Cochlodinium polykrikoides on the spotted rose snapper Lutjanus guttatus. Environ. Toxicol. 2009, 25, 319-326. [CrossRef] [PubMed]

36. Suh, S.-S.; Park, M.; Hwang, J.; Kil, E.-J.; Lee, S.; Lee, T.-K. Detection of the dinoflagellate, Cochlodinium polykrikoides, that forms algal blooms using sandwich hybridization integrated with nuclease protection assay. Biotechnol. Lett. 2015, $38,57-63$. [CrossRef] [PubMed]

37. Al-Mufta, A.; Selwood, A.I.; Foss, A.J.; Al Jabri, H.; Potts, M.; Yilmaz, M. Algal toxins and producers in the marine waters of Qatar, Arabian Gulf. Toxicon 2016, 122, 54-66. [CrossRef] [PubMed]

38. Rao, D. Short communication. Biomass and production characteristics of the first red tide noticed in Kuwait Bay, Arabian Gulf. J. Plankton Res. 1999, 21, 805-810. [CrossRef]

39. Blondeau-Patissier, D.; Gower, J.F.; Dekker, A.G.; Phinn, S.R.; Brando, V.E. A review of ocean color remote sensing methods and statistical techniques for the detection, mapping and analysis of phytoplankton blooms in coastal and open oceans. Prog. Oceanogr. 2014, 123, 123-144. [CrossRef]

40. Judice, T.J.; Widder, E.A.; Falls, W.H.; Avouris, D.M.; Cristiano, D.J.; Ortiz, J. Field-Validated Detection of Aureoumbra lagunensis Brown Tide Blooms in the Indian River Lagoon, Florida, Using Sentinel-3A OLCI and Ground-Based Hyperspectral Spectroradiometers. GeoHealth 2020, 4, 1-23. [CrossRef] [PubMed]

41. Li, J.; Tian, L.; Song, Q.; Sun, Z.; Yu, H.; Xing, Q. Temporal Variation of Chlorophyll-a Concentrations in Highly Dynamic Waters from Unattended Sensors and Remote Sensing Observations. Sensors 2018, 18, 2699. [CrossRef]

42. Matsushita, B.; Yang, W.; Chang, P.; Yang, F.; Fukushima, T. A simple method for distinguishing global Case-1 and Case-2 waters using SeaWiFS measurements. ISPRS J. Photogramm. Remote Sens. 2012, 69, 74-87. [CrossRef]

43. Overmans, S.; Agustí, S. Latitudinal Gradient of UV Attenuation Along the Highly Transparent Red Sea Basin. Photochem. Photobiol. 2019, 95, 1267-1279. [CrossRef]

44. Zhang, Y.; Pulliainen, J.; Koponen, S.; Hallikainen, M. Water quality retrievals from combined landsat TM data and ERS-2 SAR data in the Gulf of Finland. IEEE Trans. Geosci. Remote Sens. 2003, 41, 622-629. [CrossRef]

45. Moses, W.J.; Gitelson, A.A.; Berdnikov, S.; Povazhnyy, V. Estimation of chlorophyll- a concentration in case II waters using MODIS and MERIS data-successes and challenges. Environ. Res. Lett. 2009, 4, 45005. [CrossRef] 
46. El-Adawy, A.A.; Nadaoka, K.; Negm, A.; Abdel-Fattah, S.; Hanafy, M.; Shaltout, M. Characterization of the northern Red Sea's oceanic features with remote sensing data and outputs from a global circulation model. Oceanologia 2017, 59, 213-237. [CrossRef]

47. Villacorte, L.O.; Tabatabai, A.; Anderson, D.M.; Amy, G.L.; Schippers, J.C.; Kennedy, M.D. Seawater reverse osmosis desalination and (harmful) algal blooms. Desalination 2015, 360, 61-80. [CrossRef]

48. Dehwah, A.H.A.; Al-Mashharawi, S.; Kammourie, N.; Missimer, T.M. Impact of well intake systems on bacterial, algae, and organic carbon reduction in SWRO desalination systems, SAWACO, Jeddah, Saudi Arabia. Desalin. Water Treat. 2014, 55, 2594-2600. [CrossRef]

49. Anderson, C.R.; Moore, S.K.; Tomlinson, M.C.; Silke, J.; Cusack, C.K. Living with harmful algal blooms in a changing world: Strategies for modeling and mitigating their effects in coastal marine systems. In Coastal and Marine Hazards, Risks, and Disasters; Sherman, D., Ellis, J., Shroder, J., Eds.; Elsevier Inc.: New York, NY, USA, 2015.

50. Maguire, J.; Cusack, C.; Ruiz-Villarreal, M.; Silke, J.; McElligott, D.; Davidson, K. Applied simulations and integrated modelling for the understanding of toxic and harmful algal blooms (ASIMUTH): Integrated HAB forecast systems for Europe's Atlantic Arc. Harmful Algae 2016, 53, 160-166. [CrossRef] [PubMed]

51. Kurekin, A.A.; Miller, P.I.; Van Der Woerd, H.J. Satellite discrimination of Karenia mikimotoi and Phaeocystis harmful algal blooms in European coastal waters: Merged classification of ocean colour data. Harmful Algae 2014, 31, 163-176. [CrossRef] [PubMed]

52. Li, W.; El-Askary, H.M.; Manikandan, P.; Qurban, M.A.; Garay, M.J.; Kalashnikova, O.V. Synergistic Use of Remote Sensing and Modeling to Assess an Anomalously High Chlorophyll-a Event during Summer 2015 in the South Central Red Sea. Remote Sens. 2017, 9, 778. [CrossRef]

53. Cao, Y.; Wu, Y.; Fang, Z.; Cui, X.; Liang, J.; Song, X. Spatiotemporal Patterns and Morphological Characteristics of Ulva prolifera Distribution in the Yellow Sea, China in 2016-2018. Remote Sens. 2019, 11, 445. [CrossRef] 